\title{
A APLICAÇÃO DO DIREITO DO CONSUMIDOR PARA RESPONSABILIZAÇÃO CIVIL DOS FORNECEDORES DE ALIMENTOS TRANSGÊNICOS
}

\section{THE APPLICATION OF CONSUMER LAW FOR CIVIL ACCOUNTABILITY OF TRANSGENIC FOOD SUPPLIERS}

\author{
Tayrini Felizberto* \\ Adriana Carvalho Pinto Vieira** \\ Yduan de Oliveira May ${ }^{* * *}$
}

\begin{abstract}
Resumo: Ao longo das últimas décadas a polêmica sobre os transgênicos ainda é um tema bastante controverso, haja vista que a sociedade observa os experimentos com espanto e preocupação. O presente trabalho tem por objetivo analisar o tema dos alimentos transgênicos sob perspectiva da reparação dos eventuais danos causados aos consumidores por meio da responsabilidade civil objetiva presente na Lei da Biossegurança e pelo direito do consumidor consubstanciados na teoria da sociedade de risco. A partir da conceitualização do consumidor e a verificação de sua vulnerabilidade técnica, jurídica ou informacional, pode ser inferido que os danos causados aos consumidores decorrente da transgenia, têm como consequência, a responsabilização objetiva a todos os fornecedores que estiverem presentes na relação jurídica.
\end{abstract}

Palavras-chave: Direito do consumidor, alimentos transgênicos, responsabilidade civil objetiva, biossegurança, teoria do risco.

Abstract: Over the past decades the discussion over GMOs is still a very controversial topic, given that the company observes the experiments with astonishment and concern. This paper aims to examine the issue of GM food in perspective of repairing the damage caused to consumers by means of objective liability present in the Biosafety Law and the consumer law embodied in the risk society theory. From the consumer's conceptualization and verification of its technical vulnerability, legal or informational, it can be inferred that the damage caused to consumers resulting from genetic modification, have as a consequence, the objective responsibility to all suppliers that are present in the legal relationship.

Key-words: Consumer Law, GM foods, objective liability, biosafety, risk theory.

\footnotetext{
*Bacharel em Direito, UNESC. E-mail: tayrinivitali@gmail.com

** Pós-doutora, UNICAMP. Doutora em Desenvolvimento Econômico, UNICAMP. Professora do Programa de Pós-graduação em Desenvolvimento Econômico da UNESC. E-mail: dricpvieira@unesc.net

**** Mestre e Doutor em Direito, UFSC. Professor do Programa de Pós-graduação em Direito da UNESC. Pesquisador do Núcleo de Pesquisa em Estado, Política e Direito. Advogado. E-mail: yduan@unesc.net
} 
Tayrini FELIZBERTO

Adriana Carvalho Pinto VIEIRA

Yduan de Oliveira MAY

\section{INTRODUÇÃO}

Ao longo das últimas décadas a polêmica sobre os transgênicos ainda é um tema bastante controverso, haja vista que a sociedade observa os experimentos com espanto e preocupação. E isto ocorre ainda mais quando há a suspeita que algo possa colocar em risco a saúde e segurança dos indivíduos. Ainda são insuficientes as informações a respeito do assunto, e as empresas que estão envolvidas com a nova tecnologia, bem como com a nanotecnologia, não realizam a devida divulgação sobre o tema. Ressalta-se, ainda, que a oposição aos transgênicos não se limita aos movimentos preocupados com a saúde dos seres humanos e com o equilíbrio do meio ambiente. Ela é engrossada por opositores ideológicos, para os quais as grandes empresas multinacionais que produzem os transgênicos, passariam a ter controle, através do domínio da técnica, sobre a agricultura e outros setores dos países menos desenvolvidos (VIEIRA; VIEIRA JUNIOR, 2008).

A partir deste cenário, o presente trabalho tem por objetivo analisar o tema dos alimentos transgênicos sob perspectiva da reparação dos eventuais danos causados aos consumidores por meio da responsabilidade civil objetiva presente na Lei da Biossegurança (Lei $\mathrm{n}^{\mathrm{o}} 11.105 / 2005$, LB) e pelo direito do consumidor consubstanciados na teoria da sociedade de risco.

Até o ano de 2005 não era permitida a comercialização dos alimentos transgênicos. Sua liberação se deu com o advento da referida norma. Conscientes de que as evoluções da biotecnologia pudessem afetar o meio ambiente e a terceiros, esta lei foi à frente ao cuidar da responsabilidade civil objetiva. Neste sentido, a LB estabelece em seu art. 20 que os responsáveis pelos danos ao meio ambiente ou a terceiros responderão por sua indenização ou reparação, independente de culpa (BRASIL, 2005).

Neste sentido, dada a finitude dos recursos naturais, uma ação humana desenfreada pode causar danos ambientais atingindo a própria sobrevivência da humanidade. Ainda, em relação a tal aspecto, o progresso científico pode ser solução ou a causa de problemas. Assim, deseja-se evidenciar que as empresas que manipulam alimentos transgênicos devem ser civil e objetivamente responsabilizadas quando causam danos a terceiros, independente da comprovação do elemento culpa em razão do risco que tal atividade oferece aos consumidores. Os avanços tecnológicos podem evoluir a ponto de que sejam diminuídos os riscos de doenças e outros agravos na saúde do consumidor, mas o risco, mesmo que colateral e/ou mínimo, permanece. 
A Aplicação do Direito do Consumidor para Responsabilização Civil dos Fornecedores de Alimentos Transgênicos

Neste diapasão, resgata-se o Código de Defesa do Consumidor (CDC), o qual traz a proteção à vida, à saúde e à segurança ao consumidor.

Busca-se trazer à reflexão que os serviços e produtos, inclusive os alimentos transgênicos, postos à disposição no mercado de consumo não poderão causar danos à saúde do consumidor. Com a defesa da responsabilidade civil objetiva almeja-se estimular maior proteção dos consumidores vulneráveis perante aqueles que integram a cadeia de fornecimento.

2 A SOCIEDADE DE RISCO, A BIOTECNOLOGIA E OS ALIMENTOS TRANSGÊNICOS

No século XX, ocorreram eventos catastróficos, como os campos de extermínio nazistas, a bomba atômica, vazamentos radioativos de Chernobyl, entre outros. Naturalmente, os desastres oriundos do avanço tecnológico levaram os cidadãos a pensar nos riscos decorrentes.

Hoje, o risco não se limita a aventura pessoal, como nos tempos das grandes navegações, mas ocorrem também da possibilidade de autodestruição ampla, envolvendo toda a humanidade.

Nos novos experimentos não se pode de antemão conhecer e evitar todos os riscos. Ou seja, somente parte deles são mensuráveis. E, como consequência, pode haver inadvertidamente uma distribuição dos riscos, sem a verdadeira distribuição das riquezas obtidas. Explica Beck (2010, p. 235), que a passagem da distribuição de riqueza da sociedade da escassez para a distribuição dos riscos se consuma por duas condições, são elas:

\footnotetext{
Ela se consuma, em primeiro lugar - como se pode reconhecer atualmente -, quando e na medida em que, através do nível alcançado pelas forças produtivas humanas e tecnológicas, assim como pelas garantias e regras jurídicas e do Estado Social, é objetivamente reduzida e socialmente isolada a autêntica carência material. Em segundo lugar, essa mudança categorial deve-se simultaneamente ao fato de que, a reboque das forças produtivas exponencialmente crescentes no processo de modernização, são desencadeados riscos e potenciais de auto-ameaça numa medida até então desconhecida.
}

E, como elemento da força produtiva, o progresso tecnológico busca novas fronteiras. Neste sentido, nos dias atuais a biotecnologia, bem como a nanotecnologia, se apresenta como novo campo a ser explorado. Aplicada à área da agricultura, facilita a 
produção de alimentos, garantindo a melhor adaptação da planta ao solo destinado, inserindo características específicas ao alimento, através da técnica de manipulação genética.

$\mathrm{Na}$ área da saúde, a técnica da biotecnologia atua de modo a prevenir doenças, como a fabricação de vacinas, e a fim de remediá-las, com a fabricação de medicamentos específicos. Na área da indústria com a agricultura comercial em larga escala, a produção de plásticos biodegradáveis, entre outras diversas aplicações (VIEIRA; VIEIRA JUNIOR, 2008).

O termo "biotecnologia" foi aplicado, notadamente, às primeiras manipulações com organismos vivos por volta de 1800 a. C., as quais eram utilizadas leveduras (organismos vivos) para fermentar vinhos e pães. Contudo, foi somente a partir da década de 1970, que este termo ganhou força, quando foi desenvolvida a pesquisa com a engenharia genética e o descobrimento da técnica do DNA (Ácido Desoxirribonucléico) recombinante e iniciou o seu emprego na produção de alimentos.

A partir daí, passou a ser denominada de biotecnologia moderna - técnica empregada na manipulação genética de alimentos - sendo considerado um progresso da pesquisa científica com a biologia molecular e a biotecnologia aplicada à medicina (GUERRANTE, 2003).

Imediatamente, por conta da aplicação das técnicas biotecnológicas à medicina e à manipulação de alimentos surgem debates acerca da utilização de dessas técnicas de pesquisas e de aplicações nos seres humanos, nos animais e nas plantas, que ultrapassa a discussão acerca da incerteza econômica ou científica e tecnológica, mas alcança a incerteza da ética e da moral e com esta, passa a se perceber a necessidade do estudo da bioética (VIEIRA; VIEIRA JUNIOR, 2008).

Segundo Diniz (2002), ao cidadão comum aparecem os questionamentos acerca de seus limites e proteção jurídica. Neste sentido, as frequentes dúvidas sobre a correta aplicação da biotecnologia empreende a responsabilidade de não ultrapassar o limiar tênue entre a liberdade de pesquisa científica em benefício da saúde humana e os princípios constitucionais de proteção à vida (art $5^{\circ}$, caput), à dignidade da pessoa humana (art. $1^{\circ}$, III) e ao meio ambiente equilibrado (art. 225, caput) previstos na Constituição Federal de 1988 (BRASIL, 1988).

Cabe ressaltar aqui a importância da biotecnologia para a sociedade como um todo. Não obstante ser considerada uma atividade de risco, a biotecnologia é regulamentada no Brasil a partir da perspectiva do risco mínimo, sem a qual o produto não poderá ser inserido no mercado de consumo. A atividade de manipulação é considerada de risco, uma R. Fac. Dir. UFG, v. 41, n.1, p. 23-44, jan. / jun. 2017 
A Aplicação do Direito do Consumidor para Responsabilização Civil dos Fornecedores de Alimentos Transgênicos

vez que envolve organismos vivos, e implica em impactos positivos e negativos na opinião pública, razão pela qual a regulamentação desta técnica passou a ser imprescindível para dar continuidade dos avanços biotecnológicos. E nos últimos anos graças à biotecnologia, percebe-se principalmente no agronegócio, diversos avanços tecnológicos, aumentando a produtividade das culturas e, para o Brasil, o coloca como um dos principais produtores de alimento no mundo.

Guerrante (2003) define a biotecnologia moderna a partir de um conceito elaborado pelo Codex Alimentarius - "a Biotecnologia Moderna consiste na aplicação de técnicas de ácido nucléico in vitro, incluindo DNA recombinante, e a introdução direta desse ácido nucléico em células e organelas". Simplificando este conceito da biotecnologia moderna, a autora afirma que foi por meio da engenharia genética e da tecnologia do DNA recombinante - “[...] fragmento de DNA incorporado artificialmente à molécula de DNA de um vetor de clonagem que pode ser amplificado em um organismo diversas vezes. O DNA inserido no vetor de clonagem usualmente contém um gene de interesse" (GUERRANTE, 2003, p.2).

Torna-se possível modificar diretamente o conjunto total dos cromossomas de um organismo (genoma), permitindo isolar ou transferir um gene, inclusive para outra espécie. $\mathrm{O}$ gene é de suma importância no entendimento de Rodrigues (2003, p. 101), já que é aquele capaz de carregar a "herança celular" do indivíduo, constituindo o genótipo - "soma total dos fatores hereditários que o 'filho', recebe de seus 'pais"'-; o gene é constituído com um material que possui a característica de auto-reprodução, o que garante a continuidade do genótipo.

Em síntese, o isolamento dos genes de que se tem interesse é feito a partir de técnicas de clonagem, ou seja, o gene é inserido em sistemas que capacitem a purificação e recuperação do gene, onde é precedido a sua amplificação (cópias), sendo, posteriormente, incorporados por meio das técnicas de engenharia genética no genoma de um ser vivo em que se quer a característica, tornando-o um organismo geneticamente modificado.

Cabe apresentar a diferença entre os transgênicos e os organismos geneticamente modificados, que embora sejam empregados como sinônimos existe diferença entre esses dois termos. A definição dos organismos geneticamente modificados (OGM) é indicada na Lei ${ }^{\circ}$ 11.105 de 2005 , no art. $3^{\circ}$, item V, o qual retrata organismos cujo material genético (estruturas que contém informações determinantes dos caracteres hereditários transmissíveis à 
descendência) tenha sido modificado por qualquer técnica de engenharia genética (atividade de produção e manipulação de moléculas recombinantes) (BRASIL, 2005).

Vale ainda ressaltar que todo transgênico é um OGM, mas nem todo OGM é um transgênico. Isto se dá porque os organismos transgênicos são aqueles em que o gene de interesse é retirado de uma espécie diferente daquela na qual se pretende inserir o gene amplificado. Daí o nome de DNA exógenos, ou seja, são inseridos fragmentos do DNA de outra espécie no organismo-alvo da engenharia genética. Enquanto que todos os outros organismos alvos da engenharia genética são organismos geneticamente modificados (TEIXEIRA, 2008).

Conforme indicam os autores Bespalhok, Guerra e Oliveira (2000, p.16) essa modificação somente é possível com o desenvolvimento das técnicas em culturas de tecidos vegetais (e consequente produção de alimentos). E para eles:

Essas técnicas possibilitam a obtenção (regeneração) de uma planta a partir de uma única célula vegetal. Por meio das diferentes técnicas que serão apresentadas neste capítulo, é possível introduzir uma seqüência de DNA (gene) em uma célula e então regenerar uma planta transgênica a partir dessa célula transformada.

Um exemplo da aplicação da técnica de manipulação genética nos alimentos é na avaliação nutricional do produto. Os transgênicos são fruto da experiência da engenharia genética que foi capaz de descobrir e desenvolver novas formas de utilização para este ramo do desenvolvimento tecnológico a partir do mapeamento e sequenciamento das moléculas de ADN/ARN recombinante, no início da década de 90, o que culminou no desenvolvimento de uma técnica denominada transgenia, inserida no campo das biotecnologias. O primeiro produto transgênico a chegar nos supermercados foi o tomate longa vida (tomate FLAVRSAVR) nos Estados Unidos no ano de 1990 (TEIXEIRA, 2008).

Em termo que a transgenia envolve possíveis riscos oriundos das atividades de manipulação genética, a bioética e o biodireito se impõem, com o objetivo de proteger os seres vivos e o meio ambiente, estabelecendo certos limites que não devem servir como barreira ao progresso biotecnológico.

É neste cenário que trabalha a Teoria da Sociedade de Risco, demonstrando que atrás de todo o progresso tecnológico pode haver danos ainda maiores - mesmo que não diretamente -, e para a garantia da diminuição dos riscos, até quase zerá-los, o sistema jurídico, por meio de sua normatização coercitiva deve criar mecanismos para minimizar o 
A Aplicação do Direito do Consumidor para Responsabilização Civil dos Fornecedores de Alimentos Transgênicos

máximo possível os riscos provenientes das novas tecnologias, tal como previsto pela Lei da Biossegurança (LB).

\section{A LEI DE BIOSSEGURANÇA E A RESPONSABILIDADE CIVIL}

Com a Lei da Biossegurança o legislador brasileiro buscou minimizar estes riscos adotando o princípio da precaução. Uma vez que não se pode impedir o progresso tecnológico, ao mesmo tempo, deve-se garantir que haja o menor risco possível àqueles que estão envolvidos na pesquisa e, ao final, àqueles que se utilizaram da pesquisa.

No art. 20 da referida norma, dispõe-se que os danos causados a terceiros ou ao meio ambiente, por agentes que praticam as atividades elencadas possuem responsabilidade civil objetiva, independentemente da caracterização do pressuposto da culpa. Sem prejuízo da aplicação das penas previstas nesta Lei, os responsáveis pelos danos ao meio ambiente e a terceiros responderão, solidariamente, por sua indenização ou reparação integral, independentemente da existência de culpa.

A LB é um instituto que visa a prevenir um dano, quanto ao Código Civil este regula a reparação do dano já causado. Neste sentido, a LB regula o desenvolvimento e a inserção no mercado de produtos que contenham organismos geneticamente modificados, ou elementos que são provenientes destes e, quando inseridos em alimentos destinados ao consumo humano ou animal. Diante desta conceituação, é considerada essa atividade de risco.

Nessa esteira, a LB institui em seu texto a adoção do princípio da precaução que preza pela adoção de medidas que visem a não gerar o dano, ou que seja possível identificar um risco mínimo. Os eventuais riscos que envolvem a manipulação genética são enfrentados pelo princípio da prevenção, além do princípio da precaução presente no texto legal, que, em verdade são apenas um, chamado de princípio da não maleficência. Desta forma Silva (2007, p. 302) afirma que:

\footnotetext{
Diante da certeza do risco, isto é, diante de riscos demonstrados (risques avérés), o princípio da prevenção preconiza que medidas sejam adotadas para evitar o dano. $\mathrm{Na}$ área de biossegurança, quando os riscos não dependem do querer humano, ou seja, quando não é possível evitar o dano, o princípio da prevenção preconiza a adoção de medidas de proteção, visando à redução das conseqüências danosas. Tanto num quanto n’outro caso, o modelo de decisão é fundado na segurança. Considerando as hipóteses em que impera a incerteza e as informações existentes não são conclusivas, isto é, em face de riscos hipotéticos (risques hypothétiques), o princípio da precaução preconiza a adoção de medidas tendentes a não gerar o dano.
} 
Portanto, a segurança da biotecnologia deve ser encarada como uma técnica que existe o risco, e com isto, é pertinente a preocupação e a possibilidade de ser minimizado o risco, visto que não existe risco zero. E neste sentido que a legislação brasileira foi elaborado, de forma a permitir que as questões dos riscos sejam analisadas desde a proposição do projeto, abrindo a possibilidade de escolha de rotas alternativas ou de medidas de contenção que visem a manejar os risos da pesquisa, desde a fase laboratorial, passando por experimentos em casas-de-vegetação, experimentos de campo em condições controladas até a liberação no meio ambiente em larga escala (VIEIRA; VIEIRA JUNIOR, 2008).

A preocupação com este tipo de atividade é pertinente, uma vez que é através dela que a ciência se promulga capaz, por exemplo, de melhorar o rendimento, a qualidade e o valor nutritivo dos alimentos, incrementando a produção para a população constantemente crescente.

Neste sentido, é necessário que as empresas que os produzem divulguem informações acerca da manipulação genética do produto, para que os consumidores possam decidir se consomem ou não o alimento transgênico. Trata-se da observância do princípio da transparência e da informação (VIEIRA; VIEIRA JUNIOR, 2008).

Os cidadãos têm informações insuficientes acerca dos produtos geneticamente modificados e, apesar de os cientistas deterem a fórmula de como fabricar organismos geneticamente modificados com segurança, persiste inúmeros questionamentos.

Neste contexto, a responsabilidade civil se funda na atividade de risco desenvolvida pelos agentes mencionados no dispositivo legal, devendo ser observados os princípios que circundam a relação consumerista, principalmente na área dos alimentos transgênicos e na rotulagem desses produtos.

Desta feita, faz-se necessária a análise do arcabouço jurídico consumerista para proteção dos indivíduos frente aos fornecedores de alimentos transgênicos.

\section{A TEORIA DO RISCO}

Os direitos básicos dos consumidores estabelecidos no art. $6^{\circ}$ do Código de Defesa do Consumidor (CDC) são: direito à vida, à saúde, à segurança, à informação, à proteção contra práticas e cláusulas abusivas, ao equilíbrio contratual, à manutenção do contrato, à prevenção de danos, à efetiva reparação de danos, ao acesso à justiça, à facilitação 
A Aplicação do Direito do Consumidor para Responsabilização Civil dos Fornecedores de Alimentos Transgênicos

da defesa dos seus direitos e inversão do ônus da prova e à prestação adequada e eficaz de serviços públicos (BRASIL 1998).

Para Marques, Benjamin e Miragem (2010, p. 245), no rol de direitos básicos, há proteção contra riscos e referência à teoria da qualidade:

\begin{abstract}
Isto significa que ao fornecedor, no mercado de consumo, a lei impõe um dever de qualidade dos produtos e serviços que presta. Descumprindo este dever, surgirão efeitos contratuais (inadimplemento contratual ou ônus de suportar os efeitos da garantia por vício) e extracontratuais (obrigação de substituir o bem viciado, mesmo que não haja vínculo contratual, de reparar os danos causados pelo produto ou serviço defeituoso).
\end{abstract}

Aqui se percebe a responsabilidade do fornecedor, ou seja, de todo aquele que estiver envolvido na cadeia de fornecedor, de verificar a qualidade do produto e do serviço a ser prestado, para que não coloque em risco a vida ou a saúde do consumidor.

A teoria da sociedade do risco se evidencia e, neste caso, o consumidor, na sua posição de vulnerabilidade, pode, sem saber, consumir um produto ou um serviço que, por sua condição e má qualidade, poderá causar-lhe danos.

Ademais, este direito está ligado aos direitos básicos à vida e à saúde que, por sua vez, referem-se ao direito de informação prestada ao consumidor e, conforme os autores Vasconcelos e Maia (2012, p. 2): "É através da informação que o Estado aguarda ofertar meios de o próprio cidadão consumidor proteger sua saúde contra produtos ou serviços impróprios para uso ou consumo".

Acrescenta-se ao direito à vida e à saúde o direito à segurança, sendo este último ligado diretamente aos riscos decorrentes do mercado de consumo, protegendo, desta forma, o consumidor dos riscos provenientes do produto ou do serviço.

O direito à informação é muito importante na relação de consumo, pois é ele quem vai dar ao consumidor a possibilidade da escolha do produto ou serviço.

Quanto ao direito dos consumidores à proteção contra práticas e cláusulas abusivas, cuida-se aqui da proteção do consumidor a partir da consequência de reparação do dano solidária entre todos aqueles que integram a cadeia de fornecedores. Neste sentido, em caso de cláusulas abusivas, como a exoneração contratual da responsabilidade do fornecedor, serão consideradas nulas pelo CDC conforme o seu art. 51 (SILVA; LENHARDT, 2011).

Miragem (2012, p. 171) acrescenta que o equilíbrio contratual corresponde aos princípios da boa-fé, da vulnerabilidade e do equilíbrio em si, afirma, outrossim, que o 
equilíbrio contratual "é antes de tudo o equilíbrio dos interesses dos contratantes, consumidor e fornecedor".

No direito à manutenção do contrato fica estabelecido, da mesma forma que o direito à proteção contra as cláusulas abusiva, conforme o art. $6^{\circ}, \mathrm{V}$ e art. $51, \S 2^{\circ}$, ambos do CDC, que o consumidor que necessita do contrato tenha direito a mantê-lo. Do mesmo modo, os consumidores têm o direito à prevenção de danos e à sua efetiva reparação caso venham a ocorrer (BRASIL 1998). Aqui, quanto à prevenção, deve-se ser buscado o risco mínimo de dano do produto ou do serviço, uma vez que toda atividade tem um grau de risco envolvido (VIEIRA; VIEIRA JUNIOR, 2008).

No CDC estabeleceu-se a relação solidária entre os fornecedores que compõe a cadeia de consumo, relacionando alguns poucos itens que possibilitam a exclusão da responsabilidade deles. Houve a afirmação que não só os danos materiais são passíveis de reparação, mas também os danos morais, individuais, difusos e coletivos.

Consagra-se no Código o princípio da reparação integral, que pode ser facilitado pelo direito ao acesso à justiça. Refere-se ao direito dos consumidores e de seus representantes ou substitutos processuais ingressarem com ações para a defesa de seus direitos. Neste sentido, a coletividade equiparada ao consumidor será substituída em ações coletivas, que versaram sobre a defesa de seus direitos, garantindo, assim, ampla defesa de seus interesses (GRINOVER et al, 2007).

Igualmente, a inversão do ônus da prova é de suma importância, conforme esclarece os autores Marques, Benjamin e Miragem (2010, p. 258): "Exigir uma prova negativa do consumidor é imputar a este pagar duas vezes pelo lucro do fornecedor com atividades de risco no preço pago e no dano sofrido".

Neste sentido, o consumidor que é a parte vulnerável na relação consumerista e, inclusive, na relação jurídica quando há a necessidade de produção de prova contra o fornecedor, o qual é o experto sobre o produto ou serviço oferecido, o consumidor alcança a igualdade na relação.

Neste sentido, em um primeiro momento, denota-se que além de o agente ter violado um direito, ele agiu com vontade própria, sabendo dos possíveis danos que poderia causar e, já em um segundo momento, o agente violou um direito, mas sua conduta foi consequência de sua negligência, imperícia ou imprudência.

Isto porque, há no ordenamento jurídico brasileiro a aplicação da chamada teoria do risco, conforme apresenta em sua concepção Gonçalves (2011, p. 48): 
A Aplicação do Direito do Consumidor para Responsabilização Civil dos Fornecedores de Alimentos Transgênicos

Quando isto acontece, diz-se que a responsabilidade é legal ou "objetiva", porque prescinde da culpa e se satisfaz apenas com o dano e o nexo de causalidade. Esta teoria, dita objetiva, ou do risco, tem como postulado que todo dano é indenizável, e deve ser reparado por quem a ele se liga por um nexo de causalidade, independentemente de culpa.

Em análise à mencionada teoria do risco, percebe-se que em certas atividades, a lei permitirá a aplicação da responsabilidade civil objetiva quando houver um possível risco em se causar lesão. Neste caso, não será observada a culpa do agente, mas, tão somente, o nexo de causalidade e o dano causado.

Na definição de Pereira (2002, p. 284) a teoria do risco, e da obrigação de reparar o dano acontece "quando a atividade normalmente desenvolvida pelo autor do dano implicar, por sua natureza, risco para os direitos de outrem".

É assim que o legislador impõe como sendo certas atividades de risco a responsabilidade civil objetiva, uma vez que verificado o dano e nexo de causalidade e não concorrendo nenhuma das hipóteses de excludentes da culpabilidade, haverá o dever de reparar o dano.

Em análise aprofundada do tema Gonçalves (1999, p. 152), observa-se a teoria do risco indispensável para que seja garantida a proteção da sociedade frente ao progresso desenfreado:

\footnotetext{
A responsabilidade civil desloca-se da noção de culpa para a ideia de risco, ora encarada como "risco-proveito", que se funda no princípio segundo o qual é reparável o dano causado a outrem em conseqüência de uma atividade realizada em benefício do responsável (ubi emolumentum, ibi onus, isto é, quem aufere os cômodos (lucros) deve suportar os incômodos ou riscos); ora mais genericamente como "risco causado", a que se subordina todo aquele que, sem indagação de culpa, expuser alguém a suportá-lo.
}

A teoria do risco, conforme mencionada, é aquela encontrada em atividades que passam eventuais riscos ao terceiro envolvido, seja na relação de consumo, relação de trabalho e demais. Ou seja, na relação de produção, manipulação e inserção no mercado dos produtos transgênicos, pressupõe-se que nesse processo há um risco, mesmo que mínimo quando se analisa o momento anterior do produto chegar no mercado, pois este precisa passar por órgãos de controles, além de muitos anos de pesquisas - , para àquele que irá consumi-lo, no caso, o humano como destinatário final dos alimentos transgênicos, este risco deriva da 
Tayrini FELIZBERTO

Adriana Carvalho Pinto VIEIRA

Yduan de Oliveira MAY

própria manipulação do alimento, do emprego da biotecnologia (VIEIRA; VIEIRA JÚNIOR, 2008).

A teoria do risco está embasada neste progresso tecnológico, ou no caso acima empregado, no progresso biotecnológico, uma vez que o consequente avanço tecnológico empregado pelas grandes empresas comerciais, cuja ascensão está voltada para a obtenção de lucro, advém da evolução econômica. Para tanto, estas atividades comerciais são consideradas de risco àqueles que a circundam, face ao dinamismo que gira em torno dessa atividade.

O progresso econômico pode inclusive atrair risco, é neste ponto que o doutrinador Demajorovic (2003, p. 35) comenta:

[...]a produção social da riqueza na modernidade é acompanhada por uma produção social do risco. O processo de industrialização é indissociável do processo de produção de riscos, uma vez que uma das principais conseqüências do desenvolvimento científico industrial é a exposição da humanidade a riscos e inúmeras formas de contaminação nunca observados anteriormente, que ameaçam os habitantes do planeta e o meio ambiente.

No mesmo sentido, sobre a necessidade do Estado em acompanhar as mudanças da sociedade, Pancotti (2011, p. 78) abordaque as mudanças que surgem em razão, dentre outros fatores, da tecnologia e racionalização, formando um "risco coletivo":

\begin{abstract}
O incremento do risco e o esgarçamento das relações sociais também são fatores que contribuíram para retirar da culpa individual o fundamento da responsabilidade civil. Trata-se da responsabilidade coletiva, consequência de uma sociedade que incorporou o risco como preço a pagar pelo progresso tecnológico. Trata-se da denominada socialização do risco.
\end{abstract}

É visto que os cidadãos acabam se tornando dependentes dessa comercialização, do fornecimento de produtos, da prestação de serviços, deparando-se com a incerteza.

Neste cenário que trabalha a Teoria da Sociedade de Risco, demonstrando que atrás de todo o progresso pode haver danos ainda maiores, mesmo que não diretamente à sociedade.

A responsabilidade independente de culpa não extingue a responsabilidade civil subjetiva, mas, tão somente, propicia ao cidadão proteção frente ao progresso, seja tecnológico, seja econômico, seja social, sendo necessária para evitar injustiças aos cidadãos (GONÇALVES, 2011).

No Código Civil, verifica-se que no art. 932 há a modalidade da responsabilidade por ato ou fato de terceiro, e o art. 933, do mesmo diploma legal, impõe que nos casos dos R. Fac. Dir. UFG, v. 41, n.1, p. 23-44, jan. / jun. 2017 
A Aplicação do Direito do Consumidor para Responsabilização Civil dos Fornecedores de Alimentos Transgênicos

incisos do art. 932, a responsabilidade civil independerá da análise do pressuposto da culpa . Esta modalidade de responsabilidade civil consiste na vinculação indireta ao responsável, sendo contrária ao princípio geral de que a pessoa somente tem responsabilidade de seus atos pessoais. É neste sentido que se observa aquele que irá ser responsabilizado pelo fato será quem tem o dever de vigilância e cuidado daquele que causa o dano, independentemente da culpa. Para tanto, explica Diniz (2005, p. 525), que o Código Civil Brasileiro afasta a presunção juris tantum e juris et de jure o que acaba:

[...] criando, então, a responsabilidade objetiva, visto que a idéia de risco atende mais aos reclamos do mundo atual, fazendo com que o dano seja reparado pelo pai, representante legal ou empregador não porque tiveram culpa na vigilância ou escolha, mas porque correram o risco de que aquele fato lesivo adviesse.

Nesta modalidade da responsabilidade civil, também aparece a mencionada teoria do risco, já analisada, conforme se observa com a citação acima, esta modalidade em que a responsabilidade civil objetiva foi acrescentada ao novo Código Civil, tendo em vista de que o Código anterior, de 1916, previa que haveria a necessidade de comprovação da culpa daquele que detinha o dever de vigilância sobre os indivíduos elencados no dispositivo citado.

A responsabilidade civil pode ser considerada objetiva quando relativa à manipulação e inserção no mercado de consumo dos alimentos transgênicos. Isto porque se demonstrou o risco, ainda que mínimo, na produção dos transgênicos.

\section{A APLICAÇÃO DO DIREITO DO CONSUMIDOR}

O CDC é uma norma de ordem pública e de interesse social decorrentes da previsão Constitucional contida nos artigos $5^{\circ}$, inciso XXXII, e 170, inciso V.

Nesta linha, o CDC é uma norma principiológica. Isto porque decorre dos princípios da defesa do consumidor, presente no título dos direitos e garantias fundamentais, bem como do princípio previsto na ordem econômica, que tem como prerrogativa assegurar a todos a existência digna, observando-se os preceitos da justiça social e o princípio da defesa do consumidor.

$\mathrm{O}$ art. $1^{\mathrm{o}}$ do $\mathrm{CDC}$ baseado nos princípios constitucionais, refere-se à característica de uma norma de ordem pública e de interesse social, classificando-a como uma norma inderrogável, ou seja, insuscetível de disposição entre os interessados, salvo em questões patrimoniais (GRINOVER et al. 2007). 
Ao analisar a característica do interesse social, observa-se que esta característica refere-se ao cunho da função social dos contratos de consumo, uma vez que estes contratos atingem além dos interesses dos contratantes - relação privada - os interesses da coletividade latu senso. Para os autores Benjamin, Marques e Bessa (2012, p. 45) a função social que decorre do novo direito privado:

[...] é a proteção da pessoa em face dos desafios da sociedade massificada, globalizada e informatizada atual. Se as relações de consumo têm funções particulares de circulação das riquezas, a função social deve necessariamente envolver o reconhecimento da vulnerabilidade da pessoa humana, nos seus vários papéis ou status, inclusive de consumidor na sociedade de consumo atual. [...] $\mathrm{O}$ reconhecimento do papel do consumidor na sociedade (art. 5, XXXII, da CF/1988) e a necessidade de sua proteção no mercado (art. 170, V, da CF/1988) são elementos inerentes deste novo direito privado.

A norma de função social tem como característica o interesse público, sendo indisponíveis e inafastáveis por meio do contrato firmado na relação consumerista, tendo a prerrogativa de ser aplicada de ofício pelo juiz, ou seja, sua aplicação não depende do pedido da parte envolvida na relação. Deste modo, há uma relação em que são compreendidos os direitos fundamentais com eficácia horizontal, ou seja, a aplicação se dá entre aqueles indivíduos que realizaram o contrato de consumo, entre particular e particular, na relação privada (SARLET, 2005).

Neste sentido, o consumidor deve ser protegido na relação de consumo, que embora seja uma relação eminentemente privada, atinge o campo dos direitos da coletividade, uma vez que o próprio $\mathrm{CDC}$, em seu art. $2^{\circ}$, parágrafo único, revela a equiparação da coletividade de pessoas que intervieram nas relações de consumo, ainda que elas sejam indetermináveis, ao consumidor.

No CDC se tem por objetivo a proteção do sujeito, ou coletividade, consumidora, de forma a atingir um "equilíbrio negocial por meio da promoção de instrumentos de equalização. Em outros termos, assume o papel de promoção da justiça contratual" (MYSZCZUK; GLITZ, 2010, p. 2). A vulnerabilidade aqui empregada atribui-se ao consumidor frente aos fornecedores, uma vez que o primeiro - principalmente na área de biotecnologia - possui menos conhecimento técnico sobre o produto ou serviço fornecidos pelo segundo, o qual detém as informações de técnica e produção. Ela não está associada à ideia de hipossuficiência, mas sim está ligado a um estado da pessoa, frente a uma situação de 
A Aplicação do Direito do Consumidor para Responsabilização Civil dos Fornecedores de Alimentos Transgênicos

risco, uma vez que o consumidor que está frente ao fornecedor pode ter três espécies de vulnerabilidade: a técnica, a jurídica e a fática.

A vulnerabilidade técnica pressupõe que o consumidor não tenha conhecimentos específicos sobre o produto ou serviço, de forma a ficar sujeito ao bom senso do fornecedor que irá lhe vender o produto ou serviço, assim estipulasse que a vulnerabilidade é presumida para o não profissional e, excepcionalmente, para o profissional destinatário final fático do bem (MARQUES; BENJAMIN; MIRAGEM, 2010, p.198).

Já a vulnerabilidade fática caracteriza-se pela "desproporção fática de forças, intelectuais e econômicas", enquanto que a vulnerabilidade jurídica tem relação com a falta de conhecimentos jurídicos, econômicos ou de contabilidade, sendo presumíveis tão somente para os não profissionais e pessoa física, citam como exemplo os contratos de adesão. Indicando o enfoque econômico por estar ligado a ideia de que os fornecedores são os detentores dos meios de produção controlando o mercado.

Myszczuk e Glitz (2010, p. 6) acrescentam que a falta de acesso a informações no tocante àqueles produtos vinculados à biotecnologia fica muito mais evidente com a falta de divulgações dos produtos que possuem ligação com os organismos geneticamente modificados.

Por tratar-se de um princípio, a vulnerabilidade não pode ser questionada ou suprimida, haja vista ser uma qualidade inerente à pessoa que está na relação consumerista como consumidor.

O CDC se torna um microssistema jurídico (GRINOVERet al, 2007), de ordem pública e de interesse social, visa a resguardar a relação consumerista, com equilíbrio capaz de atingir a equidade entre as partes, suprimindo as vulnerabilidades eventuais e presumíveis.

A responsabilidade civil está estabelecida nos seus arts. 12 a 25. Para que a responsabilidade do fornecedor se efetive, não há necessidade de que ocorra um acidente de consumo ou "fato do produto" (art. $3^{\circ}$ do CDC). Para que isto ocorra, basta que os produtos oferecidos no mercado por estes fornecedores sejam "potenciais causadores de acidentes de consumo" (FIGUEIREDO, FIGUEIREDO e ALEXANDRIDIS, 2011). Isto porque, o CDC é favorável ao consumidor, pois há uma presunção de vulnerabilidade e hipossuficiência.

Para esta análise, necessária se faz a caracterização da relação de consumo, que, necessariamente, ocorre entre o fornecedor de produto ou serviço e consumidor, sendo que a lei determina como fornecedor (art. $3^{\circ}$ do CDC) (BRASIL, 1998): 
[...] toda pessoa jurídica ou física, pública ou privada, nacional ou estrangeira e, ainda, entes sem personalidade jurídica, que produzem, comercializam produtos, prestam serviços, entre outros, atuando direta ou indiretamente no mercado de consumo, já como consumidor, aquele que irá receber o produto ou serviço final.

O que se percebe é que o agente fornecedor está diretamente ligado com a ideia de atividade empresarial, ou seja, pessoa com propriedades disponíveis, colocando o consumidor sob uma ótica de risco, pelo fato de atualmente se viver em uma sociedade de produção em massa. É neste sentido que afirma Gonçalves (2011, p.278):

O Código de Defesa do Consumidor, atento a esses novos rumos da responsabilidade civil, também consagrou a responsabilidade objetiva do fornecedor, tendo em vista especialmente o fato de vivermos, hoje, em uma sociedade de produção e de consumo em massa, responsável pela despersonalização ou desindividualização das relações entre produtores, comerciantes e prestadores de serviços, em um polo, e compradores e usuários do serviço, no outro.

Para o CDC, o consumidor pode ser indenizado por haver vício no produto ou serviço adquirido, independentemente da comprovação da culpa, estando o primeiro conceituado no art. $3^{\circ}, \S 1^{\circ}$, do CDC, como sendo "[...] qualquer bem, móvel ou imóvel, material ou imaterial”. Quanto ao segundo, este está no art. $3^{\circ}, \S 2^{\circ}$, do mesmo Diploma Legal: "Serviço é qualquer atividade fornecida no mercado de consumo, mediante remuneração, inclusive as de natureza bancária, financeira, de crédito e securitária, salvo as decorrentes das relações trabalhistas".

A responsabilidade pelo acidente de consumo é objetiva (exceto profissionais liberais (art. $14 \S^{\circ}$ ), podendo, inclusive, um terceiro prejudicado, mas que não efetuou diretamente a relação como consumidor, ser equiparado ao consumidor, segundo o que preceitua o art. 17 do $\mathrm{CDC}$, tendo em vista que aquele que sofreu a lesão pode requerer a reparação civil pelos danos causados, sem ter a necessidade de comprovar a culpa do fornecedor do serviço ou pelo fabricante do produto.

A responsabilidade civil objetiva é encontrada no art. 12 do $\mathrm{CDC}$, em que o fabricante, produtor, construtor, nacional ou estrangeiro e do importador, ficam obrigados à reparação dos defeitos do produto ou serviço que foi adquirido pelo consumidor e, quando aqueles não forem identificados ou o vício, nos casos de produtos perecíveis, for por má conservação, o comerciante responderá como responsável para efeitos de reparação do dano, conforme preceitua o art. 13. No mais, ao comentarem o art. 12 do CDC, Gagliano e Pamplona Filho (2008, p. 262) afirmam que: 
A Aplicação do Direito do Consumidor para Responsabilização Civil dos Fornecedores de Alimentos Transgênicos

\begin{abstract}
A análise deste artigo não deixa margem a dúvidas: o legislador consagrou a responsabilidade civil objetiva nas relações de consumo. Aliás, nada mais compreensível, se nós considerarmos a hipossuficiência do consumidor e, sobretudo, o fato de que, muitas vezes, o fornecedor exerce uma atividade de risco.
\end{abstract}

Desta forma, a proteção ao consumidor envolve todos os agentes que interferem no produto final e, acerca do que dispõe o art. 18 do CDC a responsabilidade é solidária entre todos aqueles que intervirem no fornecimento ao destinatário final, o consumidor, de produtos de consumo de bens duráveis ou não duráveis. Neste sentido, o Gonçalves (2011, p. 282) afirma que:

\footnotetext{
O consumidor, em razão da solidariedade passiva, tem direito de endereçar a reclamação ao fornecedor imediato do bem ou serviço, quer se trate de fabricante, produtor, importador, comerciante ou prestador de serviços, como também pode, querendo, acionar o comerciante e o fabricante do produto, em litisconsórcio passivo.
}

Diante disso, demonstra-se que a presunção da vulnerabilidade e hipossuficiência do consumidor que tenha adquirido produto ou serviço com eventual vício, atribua ao consumidor a possibilidade de reparação do vício, uma vez que pode ingressar com ação de indenização contra aqueles que tenham interferido no produto ou serviço, direta ou indiretamente. Isto se demonstra necessário, quando se analisa que o consumidor não detém técnicas para que possa verificar o vício no produto ou serviço.

Portanto, o consumidor é o sujeito da relação jurídica que está em situação de vulnerabilidade e, neste sentido, acerca da alegada vulnerabilidade dos consumidores comentam Benjamin, Marques e Bessa (2009, p. 73) sobre a afirmação de Antônio Herman Benjamin, "é a 'peça fundamental' do direito do consumidor, é o 'ponto de partida' de toda a sua aplicação, principalmente em matéria de contratos (art. $4^{\circ}, \mathrm{I}, \mathrm{c} / \mathrm{c}$ art. $2^{\circ}$ do CDC)"'.

É nesta relação de consumo, em que o sujeito vulnerável e hipossuficiente, o consumidor, deve ser protegido dos riscos que a relação de consumo oferece. Como sempre, essa relação será efetuada com uma pessoa que conhece o produto, contra aquele que irá adquiri-lo - o consumidor.

Como já visto, em virtude do risco empregado na produção dos alimentos transgênicos, o qual é classificado como um organismo geneticamente modificado, a Lei da Biossegurança prevê a responsabilidade civil objetiva e esta, por sua vez, decorre da teoria da sociedade de risco. 
Convém neste último ponto analisar a partir do todo o que já foi apontado a respeito da responsabilidade civil objetiva, teoria do risco, a transgenia e os direitos do consumidor quais as consequências que o CDC traz para eventual dano.

De fato, a Lei da Biossegurança estabelece àqueles responsáveis por danos ao meio ambiente e a terceiros, deverão indenizar independentemente de culpa. Entretanto, há a necessidade de se identificar os responsáveis, o que é feito na relação de consumo, conforme dispõe o art. 12 do CDC, in verbis (BRASIL, 1998):

\begin{abstract}
Art. 12. O fabricante, o produtor, o construtor, nacional ou estrangeiro, e o importador respondem, independentemente da existência de culpa, pela reparação dos danos causados aos consumidores por defeitos decorrentes de projeto, fabricação, construção, montagem, fórmulas, manipulação, apresentação ou acondicionamento de seus produtos, bem como por informações insuficientes ou inadequadas sobre sua utilização e riscos.
\end{abstract}

Cabe aqui ressaltar que não se trata da análise enquanto acondicionamento de produtos perecíveis, mas sim quanto à manipulação genética praticada através da transgenia e, se acaso esta manipulação for a causa de algum prejuízo ao consumidor.

Perceba-se que o fabricante, o produtor, o construtor e o importador responderão independentemente da análise da culpa pelos danos causados aos consumidores decorrentes, neste caso, da fabricação e manipulação do alimento transgênico.

Para Benjamin, Marques e Bessa (2012, p. 160) caracteriza-se esse vício como defeitos de fabricação, para eles: “Os defeitos de fabricação - assim como os de projeto e de informação - produzem uma série de efeitos jurídicos, sendo os mais importantes deles, o dever de proceder ao recall e a obrigação de reparar os danos causados”.

Não obstante, o produto transgênico oferecido deve apresentar, sobretudo, a segurança ao consumidor, como já visto, devendo chegar-se ao risco mínimo.

O comerciante não responde solidariamente como os demais, no caso do comerciante ele só vai responder pelos danos sofridos pelo consumidor, nas hipóteses dos incisos do art. 13, quais sejam: "I - o fabricante, o construtor, o produtor ou o importador não puderem ser identificados; II - o produto for fornecido sem identificação clara do seu fabricante, produtor, construtor ou importador; III - não conservar adequadamente os produtos perecíveis."

Assim, mais uma vez, o CDC busca efetivar a proteção ao consumidor, uma vez que este é considerável vulnerável tecnicamente frente aos produtores dos alimentos 
A Aplicação do Direito do Consumidor para Responsabilização Civil dos Fornecedores de Alimentos Transgênicos

transgênicos. Corroborando a este entendimento, Policarpo (2012) afirma que: "resta claro que a imposição de limites, como forma de proteger o consumidor, tendo em vista que os efeitos futuros do uso desses alimentos são desconhecidos, visa a zelar pelo princípio da dignidade da pessoa humana, que é inerente a qualquer ser humano."

É certo que os fornecedores devem expor no mercado alimentos transgênicos que não coloquem em risco a vida e a saúde do consumidor, direitos básicos dos consumidores.

Em comum, a Lei da Biossegurança atua justamente para este fim, atuando de maneira a minimizar os riscos com a atividade ou até excluí-los, e para Silva (2007) esta ação, a biossegurança deve ser empreendida a partir de dois princípios: princípio da prevenção e o princípio da precaução.

Para Vieira e Vieira Júnior (2008, p.112): “O fornecedor está obrigado a prestar todas as informações acerca do produto ou do serviço, suas características, qualidades, riscos, preço etc., de maneira clara e precisa, não se admitindo falhas ou omissões".

Verifica-se a partir de todo este estudo que o consumidor, pessoa física ou jurídica, tem vulnerabilidade frente aos produtores de alimentos transgênicos, e em caso de dano à sua saúde ou à sua vida, podem vir a receber uma indenização, independentemente da comprovação da culpa, dos fornecedores, do produtor, do construtor e do importador.

\section{CONSIDERAÇÕES FINAIS}

Compreendeu-se a responsabilidade civil objetiva e a teoria da sociedade de risco no que tange aos eventuais danos causados aos consumidores pelas empresas que utilizam das técnicas de transgenia para a produção de alimentos.

A partir da análise, constatou-se que a responsabilidade civil objetiva advém, historicamente, da teoria da sociedade de risco, encontrada em atividades que passam eventuais riscos ao terceiro envolvido, seja na relação de consumo, relação de trabalho e demais relações. Neste sentido, há situações em que o próprio Código Civil aponta que a atividade é considerada como de risco, à qual institui a reparação do dano independentemente da verificação do risco. O mesmo ocorre com a Lei da Biossegurança que disciplina a responsabilidade objetiva em seu art. 20.

Partindo-se da teoria geral da responsabilidade civil - que, preliminarmente, a atividade de manipulação genética, correspondente ao campo da biotecnologia, é regida por princípios próprios da Bioética e do Biodireito, viu-se que a Lei da Biossegurança apresentou 
um arcabouço normativo que visa à segurança na produção, manipulação e da inserção no mercado dos organismos geneticamente modificados e, por consequência, dos alimentos transgênicos, desde que admitidos o conceito de consumidor, e a verificação de sua vulnerabilidade técnica, jurídica ou informacional.

Valendo-se da doutrina consumerista, constatou-se que os danos causados aos consumidores em decorrência do consumo de alimentos transgênicos têm como consequência a responsabilização objetiva a todos fornecedores que estiverem presente na relação jurídica, encadeados.

Neste norte, entendeu-se que o consumidor pessoa física possui vulnerabilidade frente aos produtores de alimentos transgênicos, e em caso de dano à sua saúde ou à sua vida receberá indenização, independentemente da comprovação da culpa, dos fornecedores, do produtor, do construtor e do importador.

\section{REFERÊNCIAS}

BECK, Ulrich. Sociedade de risco: rumo a uma outra modernidade. São Paulo: Ed. 34, 2010.

BENJAMIN, Antonio Herman; MARQUES, Cláudia Lima; BESSA, Leonardo Roscoe. Manual de direito do consumidor. $4^{\text {a }}$ ed. São Paulo: Revista dos Tribunais, 2012.

BESPALHOK F., J.C.; GUERRA, E.P.; OLIVEIRA, R. Melhoramento de plantas. Disponível em: <www.bespa.agrarias.ufpr.br>. Acesso em: 12 mar. 2015.

BRASIL(1988). Presidência da República. Constituição da República Federativa do Brasil de 1988. Disponível em: <http://www.planalto.gov.br/ccivil_03/constituicao/constituicao.htm>. Acesso em: 10 mai. 2015.

BRASIL (1990). Presidência da República. Lei no 8.078, de 11 de setembro de 1990. Dispõe sobre a proteção do consumidor e dá outras providências. Disponível em: <http://www.planalto.gov.br/ccivil_03/leis/L8078.htm>. Acesso em: 10 mai. 2015.

BRASIL (2002). Presidência da República. Lei no 10.406, de 10 de janeiro de 2002. Institui o Código Civil. Disponível em: <http://www.planalto.gov.br/ccivil_03/leis/2002/L10406compilada.htm>. Acesso em: 10 mai. 2015.

BRASIL (2005). Presidência da República. Lei $\mathbf{n}^{\mathbf{0}}$ 11.105, de março de 2005. Regulamenta os incisos II, IV e V do $\S 1^{\circ}$ do art. 225 da Constituição Federal, estabelece normas de segurança e mecanismos de fiscalização de atividades que envolvam organismos geneticamente modificados - OGM e seus derivados, cria o Conselho Nacional de Biossegurança - CNBS, reestrutura a Comissão Técnica Nacional de Biossegurança - 
A Aplicação do Direito do Consumidor para Responsabilização Civil dos Fornecedores de Alimentos Transgênicos

CTNBio, dispõe sobre a Política Nacional de Biossegurança - PNB, revoga a Lei no 8.974, de 5 de janeiro de 1995, e a Medida Provisória n⿳⺈ 2.191-9, de 23 de agosto de 2001, e os arts. 5ㅜㅡ, $6^{\circ}, 7^{\circ}, 8^{\circ}, 9^{\circ}, 10$ e 16 da Lei no 10.814 , de 15 de dezembro de 2003 , e dá outras providências. Disponível em: <http://www.planalto.gov.br/ccivil_03/_ato2004-2006/2005/lei/111105.htm>. Acesso em: 11 mai. 2015.

DEMAJOROVIC, Jacques. Sociedade de risco e responsabilidade socioambiental: perspectivas para a educação corporativa. São Paulo: Senac, 2003.

DINIZ, Maria Helena. Curso de Direito Civil Brasileiro: Responsabilidade Civil. 2. ed. São Paulo: Saraiva, 2002.

DINIZ, Maria Helena. Curso de Direito Civil Brasileiro: Responsabilidade Civil. 19. ed. São Paulo: Saraiva, 2005.

FIGUEIREDO, Fábio Vieira; FIGUEIREDO, Simone Diogo Carvalho; ALEXANDRIDIS, Georgios. Mini Cógido de Defesa do Consumidor: anotado. São Paulo: Saraiva, 2011.

GAGLIANO, Pablo Stolze; PANPLONA FILHO, Rodolfo. Novo curso de direitocivil: responsabilidade civil. Vol. III. São Paulo: Saraiva, 2008.

GONÇALVES, Carlos Roberto. Direito Civil: Parte Geral. 4. ed. São Paulo: Saraiva, 1999.

GONÇALVES, Carlos Roberto. Direito Civil Brasileiro: Responsabilidade Civil. Vol. 4. São Paulo: Saraiva, 2011.

GRINOVER, Ada Pellegrini et al. Código brasileiro de defesa do consumidor: comentado pelos autores do anteprojeto. 9.ed. Rio de Janeiro: Forense Universitária, 2007.

GUERRANTE, Rafaela Di Sabato. Transgênicos: uma visão estratégica. Rio de Janeiro: Interciência, 2003.

MARQUES, Claudia Lima; BENJAMIN, Antônio Herman V.; MIRAGEM, Bruno. Comentários ao código de defesa do consumidor. 3. ed. São Paulo: Revista dos Tribunais, 2010 .

MIRAGEM, Bruno. Curso de direito do consumidor. 3. ed. São Paulo: Revista dos Tribunais, 2012.

MYSZCZUK, Ana Paula; GLITZ, Frederico Eduardo Zenedin. Transgênicos e vulnerabilidade no direito do consumidor: o direito de ser informado. In Revista de Direito Público, Londrina, v. 5, n. 3, p. 01-16, dez 2010. Disponível em: <http://www.uel.br/revistas/uel/index.php/direitopub/article/viewArticle/7547>. Acesso em: 23 abr 2015.

PANCOTTI, Luiz Gustavo Boiam. Ensaio sobre a teoria da responsabilidade na sociedade de risco. Essay on the theory of liability in risk society. Revista do Tribunal Regional do Trabalho da $\mathbf{1 5}^{\mathrm{a}}$ Região, Campinas, n. 38, 2011. Disponível em: <http://bdjur.stj.jus.br/dspace/handle/2011/41527>. Acesso em: 16 mai. 2015. 
PEREIRA, Caio Mário da Silva. Responsabilidade Civil. 9ª .ed. Rio de Janeiro: Forense, 2002.

POLICARPO, Nathália Sant'Ana. O risco do desenvolvimento e a responsabilidade do fornecedor. In: Âmbito Jurídico, Rio Grande, XV, n. 106, nov 2012. Disponível em: $<$ http://www.ambito-juridico.com.br/site/?n_link=revista_artigos_leitura\&artigo_id=12402>. Acesso em: 8 maio 2015.

RODRIGUES, Silvio. Direito Civil: Responsabilidade Civil. 20. Ed. São Paulo: Saraiva, 2003.

SARLET, Ingo Wolfgang. Direitos fundamentais e direito privado: algumas considerações em torno da vinculação dos particulares aos direitos fundamentais. In: B. Cient. ESMPU, Brasília, a. 4 - n.16, p. 193-259 - jul./set. 2005.

SILVA, Adriana Martins; LENHARDT, Willian Padoan. Os Direitos Fundamentais nas relações de consumo. A tutela dos Direitos de Personalidade sob a ótica da Lei 8.078/1990. In: Â̂mbito Jurídico, Rio Grande, XIV, n. 87, abr 2011. Disponível em: <http://www.ambitojuridico.com.br/site/index.php?n_link=revista_artigos_leitura\&artigo_id=9377\&revista_cader $\underline{\text { no }=10}$ >. Acesso em: 3 maio 2015.

SILVA, Reinaldo Pereira e. A biossegurança e o instituto da responsabilidade civil. In: Revista do Instituto de Pesquisas e Estudos, Bauru, v. 41, n. 47, p. 297-316, jan./jun. 2007. Disponível em: < http://bdjur.stj.jus.br/dspace/handle/2011/35976>. Acesso em: 10 mai. 2015.

TEIXEIRA, Rodrigo de Araújo. Capacitação em melhoramento genético de plantas no Brasil: situação atual e perspectivas. Dissertação (Mestrado). Universidade Estadual de Campinas (UNICAMP), Instituto Geociências. Campinas: Unicamp, 2008.

VASCONCELOS, Fernando A. de; MAIA, Maurilio Casas. O direito à saúde na constituição e no código de defesa do consumidor.In: UniBrasil: Cadernos da escola de direito e relações internacionais, 2012. Disponível em: 〈〉. Acesso em: 2 maio 2015.

VIEIRA, Adriana Carvalho Pinto; VIEIRA JUNIOR, Pedro Abel. Direitos dos consumidores e produtos transgênicos: uma questão polêmica para a bioética e $o$ biodireito. Curitiba: Juruá, 2008.

Artigo recebido em 09 de março de 2016 e aceito em 20 de junho de 2017 